\title{
Character Association and Path Coefficient Studies for Yield and its Components in Potato (Solanum tuberosum L.)
}

\author{
R.A. Patel ${ }^{1}$, R.T. Bhavani ${ }^{1}$, Dixita K. Patel $^{2}$ and J.R. Patel ${ }^{3 *}$ \\ ${ }^{1}$ Department of Genetics and Plant Breeding, C. P. College of Agriculture, \\ Sardarkrushinagar Dantiwada Agricultural University, \\ Sardarkrushinagar - 385506 (Gujarat), India \\ ${ }^{2}$ Department of Genetics and Plant Breeding, B. A. College of Agriculture, \\ Anand Agricultural University, Anand - 388110 (Gujarat), India \\ ${ }^{3}$ Castor-Mustard Research Station, Sardarkrushinagar Dantiwada Agricultural University, \\ Sardarkrushinagar - 385506 (Gujarat), India \\ *Corresponding author
}

\section{A B S T R A C T}

Forty two diverse genotypes of potato (Solanum tuberosum L.) were evaluated for various quantitative and qualitative traits to determine the association of yield and its components. Correlation analysis revealed that the magnitude of genotypic correlation coefficient was

\section{Keywords}

Correlation coefficient, Path analysis, Tuber yield and potato

\section{Article Info}

\section{Accepted:}

12 July 2018

Available Online:

10 August 2018 higher as compared to their corresponding phenotypic correlation coefficient for most of the characters. The total tuber yield exhibited significantly positive correlation with plant height, number of stems per plant, number of tubers per plant, average weight of tubers per plant and marketable tuber yield at both genotypic and phenotypic levels. Whereas, it had significant and negative correlation with dry matter and reducing sugar at both the levels. This character showed positive and non-significant correlation with chip colour at both levels. Remaining traits were found negatively and non-significantly correlation at both levels. The path coefficient analysis revealed higher positive direct effect of tubers affected with common scab, marketable tuber yield and number of tubers per plant, while the direct effects of plant height and number stems per plant were observed negative and low in magnitude but this two character contributed indirectly via number of tubers per plant, marketable tuber yield, total soluble solid and average weight of tubers per plant towards total tuber yield. Considering the findings of correlation coefficients as well as direct and indirect effects of different yield components on total tuber yield it was suggested that greater emphasis should be laid on selection for number of tubers per plant, average weight of tubers per plant and marketable yield to achieve further improvement in tuber yield of potato.

\section{Introduction}

The history of potato is the testimony of the fact that whenever, there has been scarcity of food grains, potato has become the food security of people. Potato, because of its great utility, occupies a pre-eminent place amongst the crops and acknowledges as the "king of 
vegetables". It is also a world leading vegetable crop that furnishes appreciable amount of vitamin $B$ and vitamin $C$ as well as some minerals (Thompson and Kelly, 1957). Generally, potato produces more calories and protein per unit land area with minimum time and water than most of the major food crops (Upadhya, 1995). In India, potato is grown in 21.79 lakh hectares and production was 486.05 lakh Metric tonnes with the productivity of $22.31 \mathrm{t} / \mathrm{ha}$. The major potato growing states in the country are Uttar Pradesh, West Bengal, Bihar, Assam, Madhya Pradesh, Punjab, Gujarat and Himachal Pradesh. In Gujarat, it is cultivated in rabi season where the crop grown in 1.23 lakh hectares of area with 37.98 lakh metric tonnes production and average yield of $31.00 \mathrm{t} / \mathrm{ha}$ (Anonymous, 2017).

High yield with good quality is the most important objective in potato breeding. Tuber yield in potato is a complex character associated with many interrelated components (Murat and Vahdettin, 2004). Hence knowledge of association between yield and its component is necessary. Correlation studies would provide estimates of degree of association between tuber yield and its various components and also among the components. While path coefficient analysis further elucidates the intrinsic nature of association of component traits by determining direct or indirect contribution of various traits toward tuber yield. Therefore the aim of this study is to evaluate tuber yield components and their inter-relationship by correlation and path coefficient analysis in 42 selected and diverse genotypes of potato.

\section{Materials and Methods}

Forty two diverse genotypes were used in this experiment. These genotypes were obtained from Potato Research Station, Sardarkrushinagar Dantiwada Agricultural
University, Deesa and Central Potato Research Institute, Shimla. The 42 diverse genotypes were grown at Potato Research Station, Sardarkrushinagar Dantiwada Agricultural University, Deesa during rabi 2011-12 in a Randomized Complete Block Design with two replications. Each genotype was planted in three rows of $2.0 \mathrm{~m} \mathrm{x} 1.5 \mathrm{~m}$ size and row to row as well as plant to plant spacing were maintained $50 \mathrm{~cm}$ and $20 \mathrm{~cm}$, respectively. The recommended agronomic practices and plant protection measures were followed timely to obtain healthy crop. Five plants were selected randomly from each replication of each plot and were tagged before the emergence of tuber for the purpose of recording the observation on eleven characters viz., plant height $(\mathrm{cm})$, number of stems per plant, number of tubers per plant, average weight of tubers per plant $(\mathrm{g})$, marketable yield ( $\mathrm{t} / \mathrm{ha})$, total tuber yield (t/ha), total soluble solid (TSS), tuber dry matter $(\%)$, reducing sugar, chip colour and tubers affected with common scab per plot $(\%)$. The mean over replication of each character was subjected to statistical analysis. The genotypic and phenotypic correlation were calculated following the method of Singh and Chaudhary (1985), whereas, the path coefficient analysis as per the method given by Dewey and Lu (1959).

\section{Results and Discussion}

\section{Correlation}

The correlation coefficients between total tuber yield and its ten component characters as well as among themselves were estimated at genotypic and phenotypic levels (Table 1). In general, the values of genotypic correlation were slightly higher than their phenotypic counterpart. Higher genotypic correlations than phenotypic ones might be due to modifying or masking effect of environment in the expression of these characters under 
study. Johnson et al., (1955) also reported that higher genotypic correlation than phenotypic correlation indicated an inherent association between various characters. In few cases, the phenotypic correlation was slightly higher than their genotypic counterpart, which implied that the non-genetic causes inflated the values of genotypic correlation because of the influence of the environmental factors.

The total tuber yield showed significant and positive correlation with marketable yield $\left(r_{\mathrm{g}}=0.981\right.$ and $\left.\mathrm{r}_{\mathrm{p}}=0.977\right)$, plant height $\left(r_{g}=0.439\right.$ and $\left.r_{p}=0.398\right)$, number of stems per plant $\left(r_{g}=0.475\right.$ and $\left.r_{p}=0.478\right)$, number of tubers per plant $\left(r_{g}=0.619\right.$ and $\left.r_{p}=0.601\right)$, average weight of tubers per plant $\left(r_{\mathrm{g}}=0.425\right.$ and $\left.r_{\mathrm{p}}=0.270\right)$ at both genotypic and phenotypic levels; whereas it had significant and negative correlation with dry matter $\left(\mathrm{r}_{\mathrm{g}}=\right.$ 0.289 and $\left.r_{p}=-0.295\right)$ and reducing sugar $\left(r_{g}=-\right.$ 0.291 and $r_{p}=-0.266$ ) at both the levels. This character showed positive and non-significant correlation with chip colour at both levels. Remaining traits were found negatively and non-significantly correlation at both levels. The number of stems per plant showed positive and significant correlation with number of tubers per plant $\left(r_{\mathrm{g}}=0.739\right.$ and $\left.r_{p}=0.647\right)$, marketable yield $\left(r_{g}=0.498\right.$ and $\mathrm{r}_{\mathrm{p}}=0.476$ ) at both genotypic and phenotypic levels. This trait was positively and nonsignificantly correlated with total soluble solid and chip colour at both levels.

The number of tubers per plant was found significantly and positively correlated with marketable yield at genotypic $\left(\mathrm{r}_{\mathrm{g}}=0.587\right)$ and phenotypic $\left(r_{p}=0.559\right)$ levels. The average weight of tubers per plant had significant and positive association with marketable yield at genotypic $\left(\mathrm{r}_{\mathrm{g}}=0.464\right)$ and phenotypic $\left(r_{p}=0.320\right)$ levels; while it showed significant and negative correlation with reducing sugar at genotypic $\left(r_{\mathrm{g}}=-0.580\right)$ and phenotypic $\left(\mathrm{r}_{\mathrm{p}}=-\right.$ 0.426) levels, dry matter at genotypic $\left(r_{\mathrm{g}}=-\right.$ 0.312 ) level but non-significant at phenotypic $\left(r_{p}=-0.169\right)$ level. This character was negatively and non-significantly correlated with chip colour and tubers affected with common scab at both levels. Marketable yield was significantly and negatively correlated with dry matter $\left(r_{g}=-0.297\right.$ and $\left.r_{p}=-0.298\right)$, reducing sugar $\left(r_{g}=-0.284\right.$ and $\left.r_{p}=-0.261\right)$, tubers affected with common scab $\left(r_{g}=-0.289\right.$ and $\left.r_{p}=-0.286\right)$ at genotypic as well as phenotypic levels.

Total soluble solid was non-significantly and negatively correlated with chip colour $\left(r_{g}=-\right.$ 0.081 and $\left.r_{p}=-0.102\right)$ and tubers affected with common scab $\left(r_{g}=-0.183\right.$ and $\left.r_{p}=-0.131\right)$ at both levels. The dry matter showed nonsignificant and negative correlation with chip colour $\left(r_{\mathrm{g}}=-0.053\right.$ and $\left.\mathrm{r}_{\mathrm{p}}=-0.050\right)$ and tubers affected with common scab $\left(r_{g}=-0.092\right.$ and $\left.r_{p}=-0.090\right)$ at both levels. The reducing sugar showed non-significant and positive correlation with chip colour $\left(\mathrm{r}_{\mathrm{g}}=0.034\right.$ and $\left.\mathrm{r}_{\mathrm{p}}=0.035\right)$ and tubers affected with common scab $\left(r_{\mathrm{g}}=0.203\right.$ and $\left(r_{\mathrm{p}}=0.196\right)$ at genotypic and phenotypic levels. Chip colour showed positive but non-significant correlation with tubers affected with common scab at genotypic $\left(\mathrm{r}_{\mathrm{g}}=0.069\right)$ and phenotypic $\left(r_{p}=0.072\right)$ levels.

The results of present study are in agreement with the earlier findings for number of stems per plant by Patel et al., (2002), for plant height and number of tubers per plant by Bhagowati et al., (2002), for average weight of tubers per plant by Sanwal et al., (2003), for plant height and average weight of tubers per plant by Ragasa and Baswaraja (2005), for number of tubers per plant and average weight of tubers per plant by Luthra et al., (2005), for number of tubers per plant, average weight of a tubers per plant and dry matter content of tuber by Sattar et al., (2007), for main stem per plant, plant tubers weight and plant height by Khayatnezhad et al., (2011) and for average weight of tubers per plant by Shashikamal (2011) for different 
characters at only genotypic or both the levels.

In the present investigation, chip colour, tuber affected with common scab and total soluble solid expressed non-significant at all the characters, except, tubers affected with common scab showed negative and highly significant correlation with marketable yield. If the genetic correlation is high, the two characters can be regarded as being substantially the same and if there are no special circumstances affecting the heritability or the intensity of selection, it will make little difference in which environment the selection is carried out (Falconer, 1981). On the basis of present investigation of interrelationship, it can be presumed that for improving tuber yield in potato an ideal plant type would be more number of stems and more number of tubers per plant. Hence, these characters could be utilized as selection criteria for improving tuber yield.

\section{Path coefficient analysis}

Total tuber yield is the result of direct and indirect effects of several yield contributing characters. To know the contribution of various characters towards total tuber yield, the significant genotypic correlation of different traits with total tuber yield were partitioned into their direct and indirect effects (Table 2 and Fig. 1). The perusal of results revealed that the direct effect of plant height on total tuber yield was negative (0.431); while the indirect effect of this character on total tuber yield via number of tubers per plant (0.464), marketable tuber yield (0.434), total soluble solid (0.001), dry matter (0.006) and average weight of tubers per plant (0.134) were positive. Number of stems per plant showed positive and significant $\left(r_{g}=0.475\right)$ genotypic correlation with total tuber yield. The direct effect of number of stems per plant on total tuber yield was negative $(-0.359)$. This trait contributed indirectly towards total tuber yield via number of tubers per plant (0.462), average weight of tubers per plant (0.115), marketable tuber yield (0466), total soluble solid (0.010) and chip colour (0.012). The direct effect of number of tubers per plant on total tuber yield was positive (0.625). The indirect effect of this character on total tuber yield via average weight of tubers per plant (0.056) and marketable tuber yield (0.550) were positive. While, indirect effect of this character on total tuber yield via plant height (-0.320), number of stems per plant $(-0.265)$, total soluble solid $(-0.003)$, dry matter $(-0.016)$, reducing sugar $(-0.001)$, chip colour $(-0.001)$ and tubers affected with common scab (-0.006) were found negative. The direct effect of average weight of tubers per plant on total tuber yield was positive (0.289). The indirect effect of this character on total tuber yield via number of tubers per plant (0.121), marketable yield (0.434) and total soluble solid (0.008) were positive. While, indirect effect of this character on total tuber yield via plant height $(-0.201)$, number of stems per plant $(-0.143)$, dry matter $(-0.043)$, reducing sugar $(-0.014)$, chip colour (-0.005) and tubers affected with common scab (-0.030) were found negative. The direct effect of marketable yield on total tuber yield was positive (0.937). The indirect effect of this character on total tuber yield via number of tubers per plant (0.367), average weight of tubers per plant $(0.134)$ and chip colour (0.001) were positive.

The direct effect of total soluble solid on total tuber yield was positive (0.103). The indirect effect of this character on total tuber yield via average weight of tubers per plant (0.022) and reducing sugar (0.002) were positive. While, indirect effect of this trait on total tuber yield via plant height (-0.005), number of stems per plant (-0.034), number of tubers per plant ($0.018)$, marketable yield (-0.018), dry matter $(-0.026)$, chip colour (-0.007) and tubers affected with common scab (-0.019) were found negative. 
Table.1 Genotypic and phenotypic correlation coefficients for various characters in potato

\begin{tabular}{|c|c|c|c|c|c|c|c|c|c|c|c|}
\hline \multicolumn{2}{|l|}{ Characters } & \multirow{2}{*}{$\begin{array}{c}\text { Plant } \\
\text { height } \\
(\mathrm{cm})\end{array}$} & \multirow{2}{*}{$\begin{array}{l}\text { Number } \\
\text { of stems } \\
\text { per plant }\end{array}$} & \multirow{2}{*}{$\begin{array}{l}\begin{array}{l}\text { Number } \\
\text { of tubers } \\
\text { per plant }\end{array} \\
0.619 * *\end{array}$} & \multirow{2}{*}{$\begin{array}{l}\text { Average } \\
\text { weight of } \\
\text { tubers per } \\
\text { plant } \\
\text { (g) } \\
0.425^{* *}\end{array}$} & \multirow{2}{*}{$\begin{array}{c}\text { Marketable } \\
\text { yield } \\
\text { (t/ha) }\end{array}$} & \multirow{2}{*}{$\begin{array}{c}\text { Total } \\
\text { soluble } \\
\text { solid }\end{array}$} & \multirow{2}{*}{$\begin{array}{c}\begin{array}{c}\text { Dry } \\
\text { matter } \\
(\%)\end{array} \\
-0.289 * *\end{array}$} & \multirow{2}{*}{$\begin{array}{l}\text { Reducing } \\
\text { sugar }\end{array}$} & \multirow{2}{*}{$\begin{array}{l}\text { Chip } \\
\text { colour } \\
\\
0.027\end{array}$} & \multirow{2}{*}{$\begin{array}{c}\text { Tubers } \\
\text { affected } \\
\text { with } \\
\text { common } \\
\text { scab (\%) } \\
-0.181\end{array}$} \\
\hline Total tuber yield & $\mathbf{r}_{\mathbf{g}}$ & & & & & & & & & & \\
\hline (t/ha) & $\mathbf{r}_{\mathbf{p}}$ & $0.398 * *$ & $0.478 * *$ & $0.601 * *$ & $0.270 *$ & $0.977 * *$ & -0.043 & $-0.295^{* *}$ & $-0.266^{*}$ & 0.024 & -0.189 \\
\hline \multirow{2}{*}{$\begin{array}{l}\text { Plant height } \\
\text { (cm) }\end{array}$} & $\mathbf{r}_{\mathbf{g}}$ & & $0.435^{* *}$ & $0.742 * *$ & $0.465^{* *}$ & $0.463 * *$ & 0.011 & 0.045 & -0.147 & -0.021 & -0.075 \\
\hline & $\mathbf{r}_{\mathbf{p}}$ & & $0.382 * *$ & $0.663 * *$ & $0.288 * *$ & $0.417 * *$ & 0.021 & 0.041 & -0.119 & -0.011 & -0.070 \\
\hline \multirow{2}{*}{$\begin{array}{c}\text { Number of } \\
\text { stems per plant }\end{array}$} & $\mathbf{r}_{\mathbf{g}}$ & & & $0.739 * *$ & $0.400 * *$ & $0.498 * *$ & 0.095 & -0.175 & -0.053 & 0.140 & -0.190 \\
\hline & $\mathbf{r}_{\mathbf{p}}$ & & & $0.647 * *$ & 0.191 & $0.476 * *$ & 0.077 & -0.187 & -0.032 & 0.092 & -0.192 \\
\hline \multirow{2}{*}{$\begin{array}{l}\text { Number of tubers } \\
\text { per plant }\end{array}$} & $\mathbf{r}_{\mathbf{g}}$ & & & & 0.193 & $0.587 * *$ & -0.029 & -0.115 & -0.039 & -0.012 & -0.054 \\
\hline & $\mathbf{r}_{\mathbf{p}}$ & & & & 0.034 & $0.559 * *$ & -0.019 & -0.106 & -0.032 & -0.010 & -0.068 \\
\hline \multirow{2}{*}{$\begin{array}{l}\text { Average weight } \\
\text { of tubers per plant }\end{array}$} & $\mathbf{r}_{\mathrm{g}}$ & & & & & $0.464 * *$ & 0.076 & $-0.312 * *$ & $-0.580 * *$ & -0.053 & -0.204 \\
\hline & $\mathbf{r}_{\mathbf{p}}$ & & & & & $0.320 * *$ & -0.030 & -0.169 & $-0.426 * *$ & -0.064 & -0.166 \\
\hline \multirow{2}{*}{$\begin{array}{c}\text { Marketable yield } \\
\text { (t/ha) }\end{array}$} & $\mathbf{r}_{\mathbf{g}}$ & & & & & & -0.019 & $-0.297 * *$ & $-0.284 * *$ & 0.012 & $-0.289 * *$ \\
\hline & $\mathbf{r}_{\mathbf{p}}$ & & & & & & -0.062 & $-0.298 * *$ & $-0.261^{*}$ & 0.013 & $-0.286^{* *}$ \\
\hline \multirow{2}{*}{$\begin{array}{l}\text { Total soluble } \\
\text { solid }\end{array}$} & $\mathbf{r}_{\mathrm{g}}$ & & & & & & & -0.193 & 0.099 & -0.081 & -0.183 \\
\hline & $\mathbf{r}_{\mathbf{p}}$ & & & & & & & 0.009 & 0.064 & -0.102 & -0.131 \\
\hline \multirow[t]{2}{*}{ Dry matter $(\%)$} & $\mathbf{r}_{\mathbf{g}}$ & & & & & & & & 0.192 & -0.053 & -0.092 \\
\hline & $\mathbf{r}_{\mathbf{p}}$ & & & & & & & & 0.150 & -0.050 & -0.090 \\
\hline \multirow[t]{2}{*}{ Reducing sugar } & $\mathbf{r}_{\mathrm{g}}$ & & & & & & & & & 0.034 & 0.203 \\
\hline & $\mathbf{r}_{\mathbf{p}}$ & & & & & & & & & 0.035 & 0.196 \\
\hline \multirow[t]{2}{*}{ Chip colour } & $\mathbf{r}_{\mathrm{g}}$ & & & & & & & & & & 0.069 \\
\hline & $\mathbf{r}_{\mathbf{p}}$ & & & & & & & & & & 0.072 \\
\hline
\end{tabular}

$*$,** Significant at $\mathrm{P}=5 \%$ and $1 \%$ levels, respectively. 
Table.2 Path coefficient analysis showing direct and indirect effects of ten causal on total tuber yield variables in potato

\begin{tabular}{|c|c|c|c|c|c|c|c|c|c|c|c|}
\hline Character & $\begin{array}{l}\text { Plant } \\
\text { height } \\
(\mathrm{cm})\end{array}$ & $\begin{array}{l}\text { Number } \\
\text { of stems } \\
\text { per plant }\end{array}$ & $\begin{array}{l}\text { Number } \\
\text { of tubers } \\
\text { per plant }\end{array}$ & $\begin{array}{l}\text { Average } \\
\text { weight of } \\
\text { tubers per } \\
\text { plant }(\mathrm{g})\end{array}$ & $\begin{array}{c}\text { Marketable } \\
\text { yield } \\
\text { (t/ha) }\end{array}$ & $\begin{array}{l}\text { Total } \\
\text { soluble } \\
\text { solid }\end{array}$ & $\begin{array}{c}\text { Dry } \\
\text { matter } \\
(\%)\end{array}$ & $\begin{array}{l}\text { Reducing } \\
\text { sugar }\end{array}$ & $\begin{array}{l}\text { Chip } \\
\text { colour }\end{array}$ & $\begin{array}{c}\text { Tubers } \\
\text { affected } \\
\text { with } \\
\text { common } \\
\text { scab }(\%)\end{array}$ & $\begin{array}{c}\text { Genotypic } \\
\text { Correlation } \\
\text { of } \\
\text { total yield } \\
\text { (t/ha) }\end{array}$ \\
\hline Plant height $(\mathrm{cm})$ & -0.431 & -0.156 & 0.464 & 0.134 & 0.434 & 0.001 & 0.006 & -0.004 & -0.002 & -0.008 & $0.439^{* *}$ \\
\hline Number of stems per plant & -0.188 & -0.359 & 0.462 & 0.115 & 0.466 & 0.010 & -0.024 & -0.001 & 0.012 & -0.020 & $0.475^{* *}$ \\
\hline Number of tubers per plant & -0.320 & -0.265 & 0.625 & 0.056 & 0.550 & -0.003 & -0.016 & -0.001 & -0.001 & -0.006 & $0.619^{* *}$ \\
\hline $\begin{array}{l}\text { Average weight of tubers per } \\
\text { plant }(\mathrm{g})\end{array}$ & -0.201 & -0.143 & 0.121 & 0.289 & 0.434 & 0.008 & -0.043 & -0.014 & -0.005 & -0.021 & $0.425^{* *}$ \\
\hline Marketable yield (t/ha) & -0.200 & -0.178 & 0.367 & 0.134 & 0.937 & -0.002 & -0.041 & -0.007 & 0.001 & -0.030 & $0.981^{* *}$ \\
\hline Total soluble solid & -0.005 & -0.034 & -0.018 & 0.022 & -0.018 & 0.103 & -0.026 & 0.002 & -0.007 & -0.019 & -0.000 \\
\hline Dry matter $(\%)$ & -0.020 & 0.063 & -0.072 & -0.090 & -0.278 & -0.020 & 0.137 & 0.005 & -0.005 & -0.009 & $-0.289^{* *}$ \\
\hline Reducing sugar & 0.063 & 0.019 & -0.024 & -0.167 & -0.266 & 0.010 & 0.026 & 0.024 & 0.003 & 0.021 & $-0.291^{* *}$ \\
\hline Chip colour & 0.009 & -0.050 & -0.007 & -0.015 & 0.011 & -0.008 & -0.007 & 0.001 & 0.087 & 0.007 & 0.027 \\
\hline $\begin{array}{l}\text { Tubers affected with common } \\
\text { scab }(\%)\end{array}$ & 0.033 & 0.068 & -0.034 & -0.059 & -0.271 & -0.019 & -0.013 & 0.005 & 0.006 & 0.103 & -0.181 \\
\hline
\end{tabular}

Note: Bold diagonal value indicate direct effect

Residual effect $=-0.0067$

$*, * *$ Significant at $\mathrm{P}=5 \%$ and $1 \%$ levels respectively. 
Fig.1 Path diagram indicating direct effect of components of tuber yield and their correlation coefficient in potato

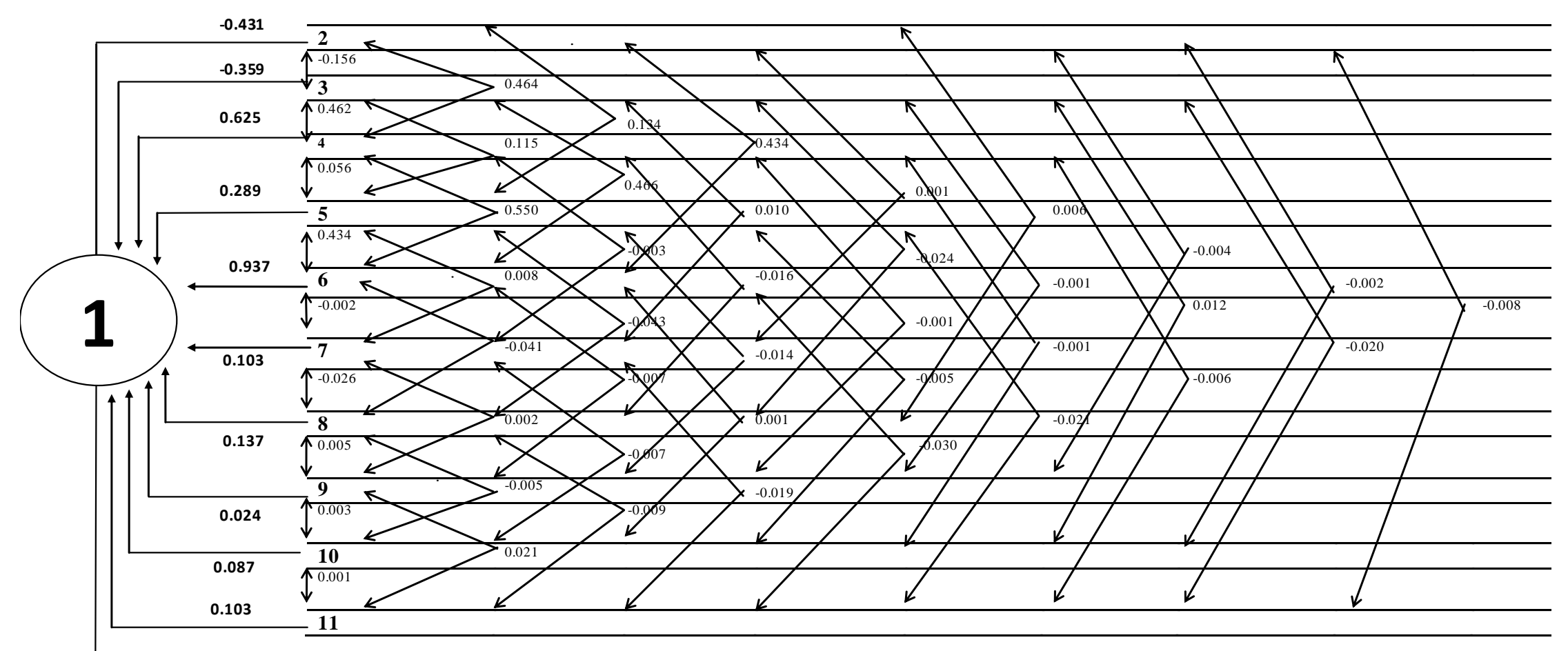

$\longrightarrow$ RESIDUAL EFFECT $=-\mathbf{0 . 0 0 6 7}$

\begin{tabular}{|l|l|l|l|}
\hline 1- Total tuber yield (t/ha) & $\begin{array}{l}\text { 5- Average weight } \\
\text { of tubers per plant }(\mathrm{g})\end{array}$ & 9- Reducing sugar & Note : \\
\hline 2- Plant height $(\mathrm{cm})$ & 6- Marketable yield $(\mathrm{t} / \mathrm{ha})$ & 10-Chip colour & (1) Right angled line arrow indicates direct effect \\
\hline 3- Number of stems per plant & 7- Total soluble solid & $\begin{array}{l}\text { 11- Tubers } \\
\text { affected with common } \\
\text { scab(\%) }\end{array}$ & $\begin{array}{l}\text { (2) Under side of curved arrow figure indicates down } \\
\text { to upper indirect effect }\end{array}$ \\
\cline { 4 - 5 } 4- Number of tubers per plant & 8- Dry matter (\%) & $\begin{array}{l}\text { (3) Upper side of curved arrow figure indicates upper } \\
\text { town indirect effect }\end{array}$ \\
\hline
\end{tabular}


The direct effect of dry matter on total tuber yield was positive (0.137). The indirect effect of this character on total tuber yield via number of stems per plant (0.063) and reducing sugar (0.005) were positive with lower magnitude. For reducing sugar direct effect on total tuber yield was positive (0.024) while the indirect effect on total tuber yield via plant height (0.063), number of stems per plant (0.019), total soluble solid (0.010), dry matter (0.026), chip colour (0.003) and tubers affected with common scab (0.021) were found positive.

The direct effect of chip colour on total tuber yield was positive (0.087). The indirect effect of this trait on total tuber yield via plant height (0.009), marketable tuber yield (0.011), reducing sugar (0.001) and tubers affected with common scab (0.007) were found positive. While, indirect effect of this character on total tuber yield via number of stems per plant (-0.050), number of tubers per plant (-0.007), average weight of tubers per plant (-0.015), total soluble solid (-0.008) and dry matter $(-0.007)$ were found negative. The direct effect of tubers affected with common scab on total tuber yield was positive (0.103). The indirect effect of this trait on total tuber yield via plant height (0.033), number of stems per plant (0.068), reducing sugar $(0.005)$ and chip colour (0.006) were positive with lower magnitude. While, indirect effect on total tuber yield via number of tubers per plant (-0.034), average weight of tubers per plant (-0.059), marketable tuber yield ($0.271)$, total soluble solid (-0.019) and dry matter $(-0.013)$ were found negative.

In the present investigation, the marketable yield, number of tubers per plant, reducing sugar, tubers affected with common scab and total soluble solid showed positive direct effect on total tuber yield (Table 2), which are in agreement with the earlier researches of Ozkaynak et al., (2003), Pandey et al., (2005),
Satya et al., (2005), Arslan (2007), and Sattar et al., (2007). The negative direct effect had been drawn for plant height and number of stems per plant on total tuber yield in present study, which was also concluded by Bhagwoti et al., (2003), Pandey et al., (2005) and Arslan (2007).

From the overall study it may be concluded that characters like number of tubers per plant, average weight of tubers per plant and marketable tuber yield exhibited strong and positive correlation as well as positive direct effect on total tuber yield, therefore, be considered as direct yield contributing characters. It would be worthwhile to lay more emphasis on these characters during selection programme aiming to improve total tuber yield in potato.

\section{References}

Anonymous, 2017. District wise area, production and yield per hectare of important food and non-food crops in Gujarat state. Directorate of Agriculture, Gujarat State, KrishiBhavan, Gandhinagar.

Arslan, B., 2007. Relationships among yield and some yield characters in potato (Solanum tuberosum L.). Journal of Biological Sciences, 7(6): 973-976.

Bhagowati, P. R., Saikia, M. and Sut, D. 2002. Variability, heritability, genetic advance and characters association in true potato seed (TPS) population. Journal of the Agricultural Science Society of North East India, 15(1): 119-122.

Dewey, D. R. and Lu, K. H., 1959. A correlation and path co-efficient analysis of crested wheat grass seed production. Agronomy Journal, 57: 515518.

Falconer, D. S. 1981. Introduction to quantitative genetics $2^{\text {nd }}$ edition, Longman, Landon, Pp. 340.

Johnson, H. W., Robinson, H. F. and Comstock, R. E. 1955. Estimates of genetic and 
environmental variability in soyabean. Agronomy Journal, 47: 314-318.

Khayatnezhad, M., Shahriari, R., Gholamin, R., Shahzad, J. S. and Roghayyeh, Z. M. 2011. Correlation and path analysis between yield and yield components in potato (Solanum tuberosum L.). MiddleEast Journal of Scientific Research, 7(1): 17-21.

Luthra, S. K., Gopal, J., Pandey, S. K. and Singh, B. P. 2005. Genetic parameters and character association in tuberosum potatoes. Potato Journal, 32(3-4): 234.

Murat, T. and Vahdettin, C. 2004. Relationships among traits using correlation and path coefficient analysis in Safflower (Carthamus tinctorius L.) sown in different fertilization levels and row spacing. Asian Journal of Plant Science, 3(6): 683-686.

Ozkaynak, E., Samanc, B. and Cetin, M. D. 2003. Correlation and path coefficient analysis of yield components in potato (Solanum tuberosum L.). Turkish Journal of Field Crops, 8(2): 51-56.

Pandey, S. K., Singh, S. V. and Manivel, P. 2005. Genetic variability and causal relationship over seasons in potato. Crop Research Hisar, 29(2): 277-281.

Patel, P. B., Patel, N. H. and Patel, R. N., 2002. Correlation and path analysis of some economic characters in potato. Journal of Indian Potato Association, 29(3-4): 163-164.

Regassa, D. and Basavaraja, N. 2005. Correlation and path analysis in potato (Solanum tuberosum L.). Potato Journal, 32(3-4): 233-256.
Sanwal, S. K., Bhutani, R. D., Khurana, S. C. and Yadav, S.P.S. 2003. Associations of tuber yield with some important physiological parameters with reference to crop duration in potato (Solanum tuberosum L.). Haryana Journal of Horticulture Science, 32(1\&2): 107110.

Sashikamal, 2011. Variability and association for morphological and biochemical traits in potato. Indian Journal of genetics, 71(1): 74-77.

Sattar, M. A., Sultana, N., Hossain, M. M., Rashid, M. H. and Islam, M. A. 2007. Genetic variability, correlation and path analysis in potato (Solanum tuberosum L.). Bangladesh Journal of Plant Breeding Genetics, 20(1): 33-38.

Satya, P. 2005. Identification of suitable vegetative parameters influencing tuber yield of early planted potato genotypes. Crop Research Hisar, 30(3): 388-392.

Singh, R. K. and Chaudhary, B. D. 1985. Biometrical methods in quantitative genetic analysis. Kalyani publ. $\left(3^{\text {rd }}\right.$ Edition), 318.

Thompson, H. C. and Kelly, W. C. 1957. Vegetable Crops. ( ${ }^{\text {th }}$ Edition). McGraw Hill Book Company, Inc. New York, Toronto and London, 611.

Upadhya, M. D. 1995. The potential of true potato seed technology for increased potato production in Bangladesh. In: National Workshop on National Programme for True Potato Seed (TPS) in Bangladesh, May 5, 1995, Bangladesh Agricultural Research Council, Dhaka, $\quad 5$.

\section{How to cite this article:}

Patel, R.A., R.T. Bhavani, Dixita K. Patel and Patel, J.R. 2018. Character Association and Path Coefficient Studies for Yield and its Components in Potato (Solanum tuberosum L.). Int.J.Curr.Microbiol.App.Sci. 7(08): 1942-1950. doi: https://doi.org/10.20546/ijcmas.2018.708.223 